\title{
PENGARUH TINGKAT PEMBERIAN PUPUK NITROGEN TERHADAP KANDUNGAN AIR DAN SERAT KASAR Corchorus aestuans
}

\author{
Anies Nuraeni ${ }^{*}$, Lizah Khairani ${ }^{* *}$, lin Susilawati* \\ Fakultas Peternakan Universitas Padjadjaran, Jalan Raya Bandung - Sumedang Km. 21 Sumedang 45636 \\ *Alumni Fakultas Peternakan Unpad Tahun 2018 \\ ** Staf Pengajar Fakultas Peternakan Universitas Padjadjaran \\ e-mail: anies2105@gmail.com
}

\begin{abstract}
ABSTRAK
Penelitian ini bertujuan untuk mengetahui pengaruh tingkat pemberian nitrogen terhadap kandungan air dan serat kasar pada hijauan Corchorus aestuans. Penelitian ini dilaksanakan di lahan Desa Panyindangan Kabupaten Purwakarta pada bulan Desember 2017 Juni 2018, dengan menggunakan metode Eksperimental, Rancangan Acak Kelompok. Terdapat enam jenis perlakuan (Po= o Kg.N.ha ${ }^{-1}$; P1 $=100$ Kg.N.ha ${ }^{-1} ; \mathrm{P}_{2}=200 \mathrm{Kg} \cdot \mathrm{N} \cdot \mathrm{ha}^{-1} ; \mathrm{P}_{3}=300 \mathrm{Kg} \cdot \mathrm{N} \cdot \mathrm{ha}^{-1} ; \mathrm{P}_{4}=400 \mathrm{Kg} \cdot \mathrm{N} \cdot \mathrm{ha}^{-1} ;$ dan $\mathrm{P}_{5}=500 \mathrm{Kg} \cdot \mathrm{N} \cdot \mathrm{ha}^{-1}$ ) dengan 4 kelompok. Hasil analisis statistik dengan analisis ragam menunjukkan bahwa pemberian pupuk Nitrogen dengan tingkatan yang berbeda tidak berpengaruh nyata terhadap kandungan air pada $C$. aestuans, sedangkan pemberian tingkat pemupukan Nitrogen pada kandungan serat kasar berpengaruh nyata. Rataan kandungan serat kasar dari masing-masing perlakuan yakni $\mathrm{Po}=22,06 \%$; $\mathrm{P} 1=22,07 \%$; $\mathrm{P} 2=20,42 \% ; \mathrm{P}_{3}=19,91 \% ; \mathrm{P} 4=16,91 \% ; \mathrm{P}_{5}=16,26 \%$. Pemberian level Nitrogen pada perlakuan $\mathrm{P}_{4}=400$ Kg.N.ha ${ }^{-1}$; dan $\mathrm{P}_{5}=500 \mathrm{Kg} . \mathrm{N} . \mathrm{ha}^{-1}$, menghasilkan serat kasar paling rendah $\mathrm{P}_{4}=16,91 \% ; \mathrm{P}_{5}=16,26 \%$ di antara yang lainnya. Semakin tinggi pemupukan semakin rendah serat kasar yang dihasilkan.
\end{abstract}

Kata kunci : C. aestuans, pupuk nitrogen, kadar air, serat kasar, hijauan.

\section{PENDAHULUAN}

Hijauan pakan merupakan salah satu faktor penentu dalam keberhasilan usaha peternakan ruminansia. Ketersediaan hijauan pakan yang tidak memadai baik kuantitas maupun kualitasnya menjadi salah satu kendala dalam pengembangan usaha peternakan, sehingga diperlukan upaya penyediaan hijauan yang cukup baik dan terjamin kualitasnya (Rostini, 2014). Hijauan pakan dapat diperoleh dari rumput, tanaman leguminosa serta lainnya, misalnya dari limbah hasil industri pertanian, seperti tebu dan padi, atau hijauan yang berasal dari tanaman yang sedang dikembangkan seperti tanaman Corchorus aestuans (C. aestuans).

Tanaman C. aestuans di beberapa negara seperti India, Filipina, dan Afrika dimanfaatkan sebagai tanaman obat serta bahan pangan, sedangkan di daerah bagian timur laut India, daun tanaman ini diberikan kepada ternak (Al-Snafi, 2016). C. aestuans memiliki palatabilitas yang baik. Tanaman ini juga memiliki zat antibakteri, antimikroba dan spasmolitik (Baskaran, dkk., 2013).Tanaman C. aestuans tumbuh secara liar dan dapat ditemukan di kabupaten Purwakarta, tepatnya di desa Panyindangan, Jawa Barat. Tanaman ini biasa disebut dengan Dengdek Poek oleh masyarakat sekitar.

Kesuburan tanah merupakan faktor yang dapat diupayakan untuk menghasilkan produksi yang optimal. Kesuburan tanah dapat ditingkatkan dengan menambahkan unsur hara berupa pupuk. Pupuk mengandung berbagai unsur hara di dalamnya, salah satunya unsur nitrogen $(\mathrm{N})$. Unsur $\mathrm{N}$ sangat penting dalam pertumbuhan tanaman yang mempengaruhi produktivitas tanaman. Nitrogen diperlukan untuk merangsang pertumbuhan vegetatif tanaman, seperti daun, batang dan akar. Unsur N berfungsi untuk meningkatkan pertumbuhan tanaman, menyehatkan pertumbuhan daun dengan warna yang lebih hijau (Sutedjo, 1999).

Kualitas hijauan pakan bergantung pada kandungan yang ada dalamnya seperti kadar air, serat kasar, protein kasar, lemak kasar, dan abu. Hijauan pakan perlu diketahui kualitasnya agar pemberiannya pada ternak lebih efektif dan efesien. Kandungan kadar air pada hijauan berhubungan dengan produksi bahan kering serta aktivitas mikrobiologis, kimiawi, enzimatik atau ketiganya yang dapat membuat kerusakan pada hijauan pakan, seperti pembusukan. Kandungan serat kasar terdiri dari selulosa, hemiselulosa dan lignin. Selulosa dan hemiselulosa merupakan bahan yang dapat dicerna oleh ternak ruminansia akan menghasilkan asam lemak terbang atau biasa di sebut VFA (volatile fatty acid), dimana VFA ini digunakan sebagai sumber energi, sedangkan lignin merupakan komponen yang tidak memiliki hasil akhir dari proses pencernaan dan keberadaannya 
dapat menghambat proses pencernaan pada ternak. Berdasarkan uraian tersebut, maka dilakukan penelitian mengenaiPengaruh Tingkat Pemberian Pupuk Nitrogen terhadap Kandungan Air dan Serat Kasar Corchorus aestuans.

\section{MATERI DAN METODE}

Bahan yang digunakan pada penelitian ini adalah Bibit C. aestuans (diperoleh dari sekitar perkebunan di Desa Panyindangan Kecamatan Sukatani Kabupaten Purwakarta, Jawa Barat), pupuk urea, arit, cangkul, sekop, meteran, alat penyiram, gunting okulasi, timbangan digital, kantong plastik, kantong kertas, spidol, dan drying oven cabinet.

Penelitian ini dilakukan dengan menggunakan metode eksperimental. Rancangan percobaan yang digunakan adalah rancangan acak kelompok (RAK), dengan 6 macam perlakuan tingkatan pemberian pupuk nitrogen pada $C$. aestuansyakni $\mathrm{P}_{0}=\mathrm{o}$ Kg.N.ha ${ }^{-1} ; \mathrm{P}_{1}=100$ Kg.N.ha ${ }^{-1} ; \mathrm{P}_{2}=200$ Kg.N.ha ${ }^{-1}$; $\mathrm{P}_{3}=300 \mathrm{Kg} \cdot \mathrm{N} \cdot \mathrm{ha}^{-1} ; \mathrm{P}_{4}=400 \mathrm{Kg} \cdot \mathrm{N} \cdot \mathrm{ha}^{-1} ; \mathrm{P}_{5}=500$ Kg.N.ha ${ }^{-1}$. Percobaan ini terdiri dari 4 kelompok berdasarkan kemiringan lahan, sehingga diperoleh 24 unit percobaan. Data yang diperoleh dianalisis menggunakan analisis ragam dan dilakukan Uji Lanjut dengan Uji Jarak Berganda Duncan. Parameter yang diamati dalam penelitian ini adalah kandungan air dan serat kasar pada tanaman $C$. aestuans.

Penelitian dimulai dari persiapan bibit $C$. aestuans dan persiapan lahan dengan ukuran petak (2x3) $\mathrm{m}^{2}$ sebanyak 24 petak, dilanjutkan dengan penanaman $C$. aestuans dengan jarak tanam (50x50) $\mathrm{cm}$, penyeragaman, pemupukan sesuai dengan perlakuan, dan pemeliharaan tanaman. Tanaman C. aestuans dipanen setelah berumur 10 minggu setelah pemupukan. Tanaman yang telah dipanen kemudian dianalisis kandungan air dan serat kasarnya dengan menggunakan analisis proksimat (AOAC, 1984).

\section{HASIL DAN PEMBAHASAN}

Rataan kandungan air, serat kasar dan lignin pada tanaman C. aestuans ditunjukkan pada Tabel 1 .

Berdasarkan Tabel 1 dapat diketahui bahwa ratarata kandungan air dalam tanaman C. aestuans pada berkisar antara 79,18-81,15\%. Berdasarkan hasil analisis ragam pemberian pupuk $\mathrm{N}$ tidak mempengaruhi kandungan air pada $C$. aestuans $(\mathrm{P}>0,05)$. Hal ini dapat disebabkan karena tingginya curah hujan pada saat penanaman $C$. aestuans yakni pada bulan Desember-Maret yang
Tabel 1. Rataan Kandungan Air, Serat Kasar dan Lignin Pada Tanaman C. Aestuans

\begin{tabular}{|c|c|c|c|c|c|c|}
\hline \multirow{2}{*}{$\begin{array}{l}\text { Kandungan } \\
\text { C. aestuans }\end{array}$} & \multicolumn{6}{|c|}{ Perlakuan } \\
\hline & Po & P1 & $\mathrm{P} 2$ & $\mathrm{P}_{3}$ & $\mathrm{P}_{4}$ & $\mathrm{P}_{5}$ \\
\hline & & & &..$\% \ldots \ldots$ & & \\
\hline $\begin{array}{l}\text { Kandungan } \\
\text { Air }\end{array}$ & $79,18^{\text {ns }}$ & $80,70^{n s}$ & $80,96^{\mathrm{ns}}$ & $80,64^{\mathrm{ns}}$ & $80,89^{n s}$ & $81,15^{\mathrm{ns}}$ \\
\hline Serat Kasar & $22,06^{\mathrm{a}}$ & $22,07^{\mathrm{a}}$ & $20,42^{b}$ & $19,06^{c}$ & $16,91^{\mathrm{d}}$ & $16,26^{\mathrm{d}}$ \\
\hline Lignin & $6,67^{\mathrm{a}}$ & $6,51^{\mathrm{a}}$ & $5,88^{\mathrm{b}}$ & $5,64^{\mathrm{c}}$ & $5,24^{\mathrm{d}}$ & $4,28^{d}$ \\
\hline
\end{tabular}

Keterangan: $\mathrm{ns}=$ non significant; huruf yang berbeda menyatakan perlakuan berbeda nyata.

merupakan bulan basah.Menurut Balai Besar Teknologi Modifikasi Cuaca, tercatat pada saat penelitian berlangsung yakni pada 26 Desember 2017 sampai 6 Maret 2018 terjadi curah hujan dibawah $0,5 \mathrm{~mm}$ dan tidak hujan tercatat 12 hari, dan 58 hari turun hujan,dimana total curah hujan $>100 \mathrm{~mm} /$ bulan. Pada bulan basah, tanaman lebih banyak mengandung air dibandingkan dengan bahan kering. Curah hujan yang tinggi menyebabkan pencucian unsur hara dalam tanah sehingga unsur hara dalam tanah tidak maksimal terserap, hal ini didukung dengan pendapat Sarief (1986) bahwa berkurangnya unsur hara dalam tanah adalah karena terangkut pada waktu panen, pencucian dan pada peristiwa erosi.

Kandungan air dalam suatu bahan berhubungan dengan kandungan bahan kering yang terdapat di dalamnya. Pengaruh pemberian pupuk $\mathrm{N}$ terhadap kandungan air yang tidak berbepengruh nyata ini berhubungan pula dengan kandungan bahan keringnya. Hal ini sesuai dengan pendapat Fathul dkk., (2003) bahwa kandungan bahan kering pada musim hujan lebih rendah dibandingkan dengan musim kemarau. Namun, berbeda dengan penelitian yang dilakukan oleh Olaniyi dan Ajibola (2008) pada tanaman C. olitorius, yang merupakan tanaman yang berasal dari keluarga yang sama. Hasil penelitiannya menunjukkan bahwa pemberian pupuk $\mathrm{N} 45 \mathrm{~kg} \cdot \mathrm{ha}^{-1}$ dan fosfor $30 \mathrm{~kg} \cdot \mathrm{ha}^{-1}$ pada tanaman Corchorus olitorius meningkatkan tinggi tanaman, jumlah daun, tunas, bahan kering dan hasil biji corchorus di atas kontrol (yang tidak menggunakan pupuk). Kandungan air yang tinggi pada tanaman $C$. aestuans dapat dikatakan karena terangkutnya unsur hara akibat pencucian saat hujan. Namun kandungan air pada hijauan ini masih termasuk ke dalam kadar normal, sesuai dengan pendapat Tilman dkk., (1989) yang menyatakan bahwa biasanya tanaman yang masih muda mengandung air antara $70.80 \%$ dari berat segarnya.

Tabel 1 menunjukkan bahwa pengaruh pemberian pupuk $\mathrm{N}$ berpengaruh nyata $(\mathrm{P}<\mathrm{O}, \mathrm{O} 5)$ terhadap serat kasar tanaman $C$. aestuans. 
Pemberian pupuk $\mathrm{N}$ yang mempengaruhi serat kasar. Pemberian pupuk $\mathrm{N}$ yang semakin banyak membuat kadar serat kasar pada menjadi lebih berkurang. Tanaman $C$. aestuans yang tanpa pupuk dan yang diberi pupuk $100 \mathrm{Kg}$. N. ha ${ }^{-1}$ masingmasing memiliki kandungan serat kasar paling tinggi yakni 22,06 dan 22,07\%, sedangkan tanaman yang diberi pupuk $\mathrm{N}$ sebanyak 400 dan $500 \mathrm{~kg}$. N. ha ${ }^{-1}$ memiliki kadar serat kasar paling rendah yakni $16,917 \%$ dan $16,263 \%$.

Menurut Sarief (1986) unsur hara dalam tanah yang tersedia bagi tanaman terdapat dalam dua keadaan, yaitu dalam bentuk garam yang terlarut menjadi ion dalam larutan tanah dan dalam bentuk terikat pada permukaan koloid kompleks dan humus atau kompleks adsorpsi. Nitrogen sendiri diserap baik dalam bentuk ammonium $\left(\mathrm{NH}_{4}+\right)$ maupun nitrat $\left(\mathrm{NH}_{3}-\right)$. Ketersediaan $\mathrm{N}$ dalam tanah diikat oleh tanaman melalui akar dengan dibantu oleh organisme yang ada dalam tanah. Nitrogen yang terserap oleh tanaman kemudian digunakan untuk merangsang pertumbuhan vegetatif tanaman, seperti daun, batang dan akar. Unsur $\mathrm{N}$ berfungsi untuk meningkatkan pertumbuhan tanaman, menyehatkan pertumbuhan daun dengan warna yang lebih hijau (Sutedjo, 1999). Unsur N dalam tubuh tanaman dijumpai dalam bentuk anorganik yang bergabung dengan unsur $\mathrm{C}, \mathrm{H}$, dan $\mathrm{O}$ membentuk asam amino, enzim, asam nukleat, dan klorofil, sehingga dapat meningkatkan laju fotosintesis (Fathan, 1998). Meningkatnya laju fotosintesis ini meningkatkan pula kandungan karbohidrat yang ada pada tanaman . Karbohidrat yang dihasilkan dimanfaatkan oleh tanaman untuk terus melakukan pembelahan sel. Tanaman muda yang mengalami pembelahan sel ini memiliki isi sel yang lebih tinggi dan memiliki dinding sel yang belum terlalu tebal atau tipis. Hal ini sejalan dengan pernyataan Sarief (1984) bahwa semakin tinggi pemberian nitrogen, semakin cepat sintesis karbohidrat yang diubah menjadi protein dan protoplasma, dengan demikian semakin kecil perbandingan yang tersedia untuk bahan dinding sel. Jumlah nitrogen yang terlalu banyak mengakibatkan menipisnya bahan dinding sel. Sebaliknya, kandungan $\mathrm{N}$ yang rendah dapat mengakibatkan tebalnya dinding sel daun dengan ukuran sel yang kecil, dengan demikian daun menjadi keras dan penuh dengan serat-serat.

Dinding sel sendiri terdiri dari hemiselulosa dan lignoselulosa (lignin dan selulosa) yang merupakan fraksi serat kasar (Tilman, dkk., 1989). Tanaman yang diberi pupuk $\mathrm{N}$ dengan level tinggi melakukan pertumbuhan dengan optimal sehingga kandungan proteinnya lebih tinggi dan serat kasarnya rendah. Hal ini sesuai dengan penelitian yang dilakukan oleh
Kaca (2011), pemupukan yang dilakukan dengan rentang 0-400 kg.N.ha ${ }^{-1}$ pada rumput Paspalum stratum menunjukkan semakin tinggi tingkat pemupukan maka menghasilkan peningkatan berat kering dan protein kasar, serta penurunan serat kasar. Hasil serat kasar pada tanaman C. aestuans tidak jauh berbeda dengan tanaman lainnya yang berasal dari keluarga yang sama, seperti serat pada tanaman C. capsularis sebesar 15,20\% (Khanom et. al., 2012). Sedangkan pada C. olitorius yaitu serat kasarnya jauh lebih tinggi yakni sebesar 20,30 g. $\mathrm{Kg}^{-1}$ pada daun dan $35,50 \mathrm{~g}$. $\mathrm{Kg}^{-1}$ pada batang (Ndlovu dan Afolayan, 2008).

Serat kasar terdiri dari hemiselulosa, selulosa, dan lignin. Hemiselulosa dan selulosa dapat dicerna oleh ternak sedangkan lignin merupakan komponen yang tidak memiliki hasil akhir dari proses pencernaan dan keberadaannya dapat menghambat proses pencernaan pada ternak. Pemberian serat kasar pada ternak dibatasi oleh kandungan lignin didalamnya. Tabel 1 menunjukkan bahwa kandungan lignin yang terkandung pada tanaman C. aestuans berkisar $4,28-6,67 \%$. Hasil analisis ragam menunjukkan bahwa pemberian pupuk $\mathrm{N}$ berpengaruh terhadap kandungan lignin pada tanaman C. aestuans. Pemberian pupuk $\mathrm{N}$ yang semakin besar menurunkan kandungan lignin. Pemberian pupuk pada tanaman $C$. aestuans sebanyak $500 \mathrm{~kg}$. N. ha ${ }^{-1}$ memiliki kandungan lignin yang paling rendah yakni 4,28\%, sedangkan pada tanaman C. aestuans yang tidak diberi pupuk $\mathrm{N}$ memiliki kandungan lignin paling tinggi yakni 6,67\%. Menurut Zulbardi, dkk (1999) batas toleransi lignin untuk ternak ruminansia adalah 7\%. Hal ini dapat dikatakan bahwa tanaman $C$. aestuans dapat diberikan kepada ternak secara langsung tanpa diolah. Kandungan lignin yang rendah dikarenakan terbentuknya dinding sel yang tipis akibat dari pertumbuhan pada fase vegetatif yang optimal. Tabel 1 memperlihatkan bahwa penurunan serat kasar juga diikuti oleh penurunan kandungan lignin.

\section{KESIMPULAN}

Berdasarkan hasil penelitian dan pembahasan, dapat disimpulkan bahwa :

1. Pengaruh pemberian pupuk Nitrogen tidak mempengaruhi kandungan air tanaman $C$. aestuans tetapi mempengaruhi serat kasar tanaman C. aestuans.

2. Tingkat pemberian pupuk Nitrogen yang optimal untuk menghasilkan kandungan air dan serat kasar yang paling rendah untuk tanaman $C$. aestuans adalah 500 Kg.N.ha ${ }^{-1}$. 


\section{DAFTAR PUSTAKA}

Al-Snafi AE. 2016. The Constituents and Pharmacology of Corchorus aestuans: A Review: The Pharmaceutical and Chemical Journal, 2016. Department of Pharmacology, College of Medicine, Thi qar University. Nasiriyah, Iraq. 3(4):208-214.

AOAC. 1984. Official Methods of Analysis of Assosiation of Official Chemist. $14^{\text {th }}$ ed. Arlington, Virginia: AOAC, Inc.

Baskaran, C., Ratha Bai, V., Sivamani, P., and Thiagarajan. 2013. Phytochemical Investigation And Anti Microbial Activity Of Corchorus Aestuans (Tiliaceae). The Pharmaceutical and Chemical Journal. [Online] Tersedia Di International Journal Of Current Research. Diakses pada 29 Desember 2017 pukul 20.30 WIB.

Fathan, R. M., Raharjo, A.K., dan Makarim. 1998. Hara tanaman jagung. Dalam: Jagung. Subandi et al. (Eds.). Puslitbangtan. Bogor.

Fathul, F., Liman, N. Purwaningsih, dan S. Tantalo Y.S. 2003. Pengetahuan Pakan dan Formulasi Ransum. Universitas Lampung. Bandar Lampung.

Kaca, I. N. 2011. Pemberian Pupuk Nitrogen untuk Meningkatkan Produksi dan Kualitas Hijauan Rumput Pasapalum Tratum. Singhadwala. 44:30.

Khanom, S., Sonia and Shahid. 2012. Effects $O f N, P, K$ And S Application On Yield And Quality Of White
Jute (Corchorus capsularis L.) Var. Bjc 2197. Dhaka Univ. J. Biol. Sci. 21(2): 109-116

Ndlovu, J and AfolayanA.J, 2008. Nutritional Analysis of the South African Wild Vegetable Corchorus olitorius L.. Asian Journal of Plant Sciences, 7: 615-618.

Olaniyi, J.O. and Ajibola, A.T.; Growth and Yield Performance of Corchorus olitorius Varieties as Affected by Nitrogen and Phosphorus Fertilizers Application, Am.-Eurasian J. Sustain. Agric., 2(3): 235-241

Rostini T. 2014. Produktivitas dan Pemanfaatan Tumbuhan Rawa di Kalimantan Selatan Sebagai Hijauan Pakan Berkelanjutan. Disertasi Doktor Pascasarjana Institut Pertanian Bogor. Bogor Sarief, S. 1985. Kesuburan dan Pemupukan Tanah Pertanian. Pustaka Buana, Bandung. 5-24 Setyati, S. 1996. Pengantar Agronomi. PT. Gramedia Pustaka Utama. Jakarta.

Sutedjo, MM. 1999. Pupuk dan Cara Pemupukan. Rineka Cipta. Jakarta.

Tillman, A. D., H. Hartadi, S. Reksohadiprodjo, S. Prawiro Kusuma, dan S. Lebdosoekoekojo.

1998. Ilmu Makanan Ternak Dasar. Gadjah Mada University Press, Yogyakarta. 140-143 Zulbardi, M., Tatit Sugiarti, N. Hidayati dan Abdurrays Ambar Karto. 1999. Peluang Pemanfaatan Limbah Tanaman Tebu untuk Penggemukan Sapi Potong di Lahan Kering.Jurnal Wartazoa. Balai Penenlitian T 